\title{
An investigation of the suitability of a Servant Leadership model for academic Group Leaders at German universities
}

\author{
Dr. Jochen Moll \\ Goethe University of Frankfurt am Main \\ Prof. Louise Kretzschmar \\ University of South Africa
}

\begin{abstract}
Due to the many changes that have occurred over the last two decades, especially in connection with the 'new managerialism', academia is a complex working environment. Multiple skills are demanded from professors, such as acting as entrepreneurs and mentors with designated leadership competences. This paper investigates the leadership role of academic group leaders in the context of higher education in Germany. It is argued that a servant leadership approach can enable professors to provide effective academic leadership in the current university context. This is due to its strong human orientation and low power distance and its focus on facilitating academic excellence, creativity and innovation. The discussion notes the importance of developing academic group leaders and describes some practical means of implementing servant leadership in higher education.
\end{abstract}

\section{Introduction: The German context of academic group leaders}

Higher education in Germany is comprised of public Universities, private Universities, Universities of Applied Sciences and Universities of Cooperative Education. Currently, research endeavours are being expanded through different forms of cooperation between universities, research institutions and both public and private businesses (Hans Böckler Stiftung, 2010). According to the Federal Statistical Office, in the 2015/2016 academic year 427 state-registered or state-recognized Higher Education Institutions (HEIs) in Germany are listed, i.e., Universities (107), Universities of Applied Sciences (216), Colleges of Art (52), Colleges of Public Administration (30), Theological Colleges (16), and Colleges of Education (6), cf. (Federal Statistical Office, 2016a). At these HEIs, a total number of 46310 professors are employed and 2.8 million students are registered (Federal Statistical Office, 2016b).

In recent years the German academic landscape has changed dramatically due to the New Public Management (NPM) model or 'new managerialism' (Hüther, 2010). Previously, professors managed the academic processes within a faculty, but since most professors are neither qualified nor experienced as managers, such self-governance is considered by some to be unprofessional (Vogel, 2009). The recent NPM reforms have strengthened the position of the university president and the central management (Hüther, 2010). This has resulted in a shift of power from academics to central managerial units (Macfarlane, 2012). This top-down structure, drawn from the corporate world, has partly replaced the longstanding paradigm of professorial collegiality (Hüther, 2010). In this new managerial approach, a successful professor is expected to demonstrate not only excellence in his/her field of research and teaching, but also management skills and, in particular, leadership competence within the university (Peus et al., 2010a) and (Carmesin et al., 2014). 
In order to become a professor in Germany, and in many other countries, the candidate has to meet several expectations ranging from excellent scientific publications in peerreviewed journals to the attaining of research grants, scientific awards, contributions to academic and professional bodies and to have outstanding teaching skills (Macfarlane, 2012). Mobility, internationality and availability at all times are required (Klinkhammer, 2014), plus a certain 'X-factor', such as natural authority, a strong presence, or special empathy (Macfarlane, 2012). According to Jungbauer-Gans and Gross (2013), the likelihood of being appointed as a professor is improved if the candidate is young and has demonstrated a high level of 'productivity'. In Germany on average, academics become professors at the age of 40 (Krimmer et al., 2004). But, as Macfarlane (2007) points out:

The irony is that in a modern context to become a Professor calls for a selfish, individual pursuit of publications and research grants while discharging the wider moral responsibilities of being a Professor demands a more selfless set of qualities that nurture others and encourage collective interests.

It is noteworthy that leadership competences are seldom a condition for academic appointments in German higher education institutions (Peus et al., 2010a). This fact is criticized by the German University Association of Advanced Graduate Training (GUAT) in Carmesin et al. (2014). At present, in Germany there are few systematic programs to prepare researchers for leadership and management responsibilities (Schmidt, 2010). An exception is the LudwigMaximilians-Universität in Munich which has developed a program where scientific staff are able to develop their leadership skills (Weisweiler et al., 2011), (Braun et al., 2009). Other universities, such as the Goethe-University of Frankfurt am Main, now follow this example.

Also vitally important in the German context is academic freedom. Wilhelm von Humboldt (1767-1835) defined the university landscape in Germany with his concept of solitude and freedom. He stressed academic freedom, intellectual rigor, merit and the cultivation of the broad concept of Wissenschaft, which includes the study of religion, the natural and human sciences (Jeynes and Robinson, 2012). This means that a university should have the opportunity to perform research and teaching independent of state and church control. Academic autonomy is a cornerstone of German academic identity. It encapsulates the 'freedom of thought and expression essential to creativity and criticism' (Macfarlane, 2012). After 1945, the relationship between the German state and the universities in Germany changed (Hüther, 2010) and academic freedom, especially the freedom of research and teaching are now guaranteed by Art. 5 Abs. 3 in the Basic Law of the Federal Republic of Germany:

Kunst und Wissenschaft, Forschung und Lehre sind frei. Die Freiheit der Lehre entbindet nicht von der Treue zur Verfassung (Art. 5 Abs. 3 GG).

(Own translation: "Art and science, research and teaching are free. The freedom of teaching does not absolve one from loyalty to the constitution").

In the light of this brief explanation of the context of academic group leaders in Germany, it is important to define what is meant by the term and to outline the methodology employed in this article. Thereafter we ask what kind of leadership is appropriate within the current higher education sector (Schmidt and Richter, 2009). 


\section{Key definitions and methodology}

The term 'academic group leadership' has different meanings in the literature. It is related to research leadership (Middlehurst et al., 2009), intellectual leadership (Macfarlane, 2012), professorial leadership (Evans et al., 2013) or campus leadership (Rowley and Sherman, 2003). Basically, 'academic group leadership' involves the leadership of professional academics i.e., the promotion of the creativity and productivity of group members (Hemlin et al., 2013).

In this article, the term 'academic group leadership' refers to the leader of an academic working group in higher education institutions, typically, but not necessarily, represented by a professor. Depending on the research discipline, such a research group consists of $\mathrm{PhD}$ students, post-doctoral students, non-scientific staff, and Bachelor and Masters students. In Germany, special types of research groups exist such as the Emmy Noether Group of the German Research Foundation. In this group, the group leader does not have the formal status of a professor, but has similar academic duties. Such scientists are therefore included in this analysis.

This discussion draws on the general field of leadership studies, and specifically on literature related to tertiary education. This interdisciplinary approach engages with management studies, especially the approach of servant leadership, business ethics, and theological leadership studies (Kessler and Kretzschmar, 2015).

In the current literature, many leadership styles are discussed in the context of universities in the United Kingdom and elsewhere, such as Collegiate leadership, Transactional leadership, Transformational leadership, Collective leadership, Managerialist leadership, Remote or Distant leadership and Hybrid Management (Rayner et al., 2010). For example, Gregory Stone et al. (2004) compares servant leadership with transformational leadership in terms of their similarities and differences. A similar approach can be found in Reinke (2004). A comparison of servant leadership, authentic and ethical leadership is found in van Dierendonck (2011). Barbuto (2006) compares servant leadership with transformational leadership and leader-member-exchange (LMX) theories. Sendjaya and Sarros (2002) see significant gaps between servant and charismatic leadership although they share common biblical roots. Both transformational and servant leadership are seen as dynamic leadership models that are suitable for a fast changing world (Gregory Stone et al., 2004). In addition to the many conceptual papers dealing with servant leadership characteristics, some authors call for an evaluation of servant leadership and improved servant leadership theory (Barbuto, 2006), (Berger, 2014).

This article investigates the leadership role of academic group leaders at German HEIs typically, but not necessarily, represented by a professor. This topic is of particular interest for HEIs in Germany, because some professors do not see themselves in a leadership role (Schmidt and Richter, 2008). The hypothesis of this article is that 'Servant leadership is a suitable leadership model for academic group leaders in contemporary German universities'. This theoretical research seeks to clarify and extend the understanding of servant leadership and relate it to academic group leadership. It further shows how servant leadership can both advance the work of academic units or departments and resist the hierarchical tendencies of the new 'managerialism' at the departmental level. In addition we fill an existing gap in the servant leadership literature by providing practical suggestions of how servant leadership can be 
exemplified by academic group leaders. Although the focus of this research is on HEI in Germany, the findings may also be applicable to other countries (Parris and Peachey, 2013).

Servant leadership is a term that was introduced to leadership and management studies by Robert K. Greenleaf (1977) several decades ago. Greenleaf worked for the American communications firm AT \& T, and one of the roots of his understanding of leadership was that of the Judaeo-Christian faith, especially the Quaker tradition (Bekker, 2010). Hence, servant leadership is often linked to a Christian and biblical perspective on leadership (Flanike, 2006) and the words of Jesus in Mark 9:35 (New International Version), 'Anyone who wants to be first must be the very last, and the servant of all.' (Flanike, 2006). Greenleaf believed that the notion of a servant leader was valid for all institutions and faiths. Although its biblical origins cannot be overlooked, this leadership model is not limited to Christian academics or theological studies (Wheeler, 2012); there are also secular versions of the servant leadership approach. Examples include its use in the areas of business, psychology, nursing, management, personal selling and sales management, ethics, parks and recreation administration, services marketing and sports (Parris and Peachey, 2013).

For the sake of brevity, the following aspects are not addressed in this discussion:

- Many publications on academic leadership deal with university or faculty leadership, but the focus of this research is on academic group leaders who are embedded in a faculty and university environment. Therefore, university or department leadership will not be addressed.

- No detailed discussion of different leadership styles will be provided, such as transformational leadership or adaptive leadership (McClellan, 2013). Only the servant leadership model with its multiple facets will be considered here, although reference to the literature that compares servant leadership with other leadership models is provided.

- Gender and diversity aspects are not considered here in detail (Acker, 2012).

- Since multiple cultures are present at a university, academic group leaders are faced with the cultural dimensions of leadership and with different religions that are linked to the cultural diversity. However, leadership issues related to specific cultures, such as African vs. Asian cultures, and religions, such as Islam and Hinduism, are not studied.

\section{Servant leadership: What is it?}

As a reaction to scandals in the business world such as those of Enron, WorldCom, Lehman Brothers and, more recently, Volkswagen, there is an increased interest in leadership models that have distinct moral and ethical dimensions (Peus et al., 2010b). Servant leadership is seen as an approach that can demonstrate this moral and ethical dimension (Barbuto, 2006). Parris and Peachey (2013) claim that it is a leadership style that can help to address the 'challenges of the twenty-first century: technological advancements, economic globalization, increased communications, the Internet, rising terrorism, environmental degradation, war and violence, disease and starvation, threat of global warming, intensifying gap between the poor and rich worldwide, as well as many other unsolved issues'.

In a recent literature review on servant leadership, Parris and Peachey (2013) mention that three publications are often cited in studies dealing with servant leadership. First, Robert K. Greenleaf (1977) describes servant leadership in the following way, 
The best test and difficult to administer, is: Do those served grow as persons? Do they, while being served, become healthier, wiser, freer, more autonomous, more likely themselves to become servants? And, what is the effect on the least privileged in society; will they benefit, or, at least, not be further deprived? (Greenleaf, 1977)

This understanding of servant leadership stresses an orientation towards the needs of others (Wheeler, 2012). Hence, in their doctoral supervision, academic group leaders wish to see their students growing, not only professionally, but also personally.

A second approach to servant leadership theory is provided by Spears (2004) who introduces ten characteristics of a servant leader, i.e. listening, empathy, healing, awareness, persuasion, conceptualizing, foresight, stewardship, commitment to the growth of people, and building community. We return to these ten characteristics below.

Thirdly, Laub (1999) identifies six areas of servant leadership in his Organizational Leadership Assessment (OLA), i.e. values people, develops people, builds community, displays authenticity, provides leadership and shares leadership.

Finally, another conceptual model of servant leadership is proposed by van Dierendonck (2011) where servant leadership can be described with the following characteristics: empowering and developing people, humility, authenticity, interpersonal acceptance, providing direction and stewardship. We can see from these definitions that although consensus on the nature of servant leadership theory does not exist at present (van Dierendonck, 2011), general agreement on its characteristics can be detected.

Compared to these positive assessments, there are some writers who are critical of servant leadership. Eicher-Catt (2005) states that it is not a panacea and Sendjaya and Sarros (2002) argue that the term servant leader is an oxymoron; it stands for a person who is a leader and servant at the same time. This term is also problematic for Berger (2014), who believes that the word 'servant' does not have an inspiring meaning but instead 'suggests passivity and indecisiveness and, even more, letting go of power' (van Dierendonck, 2011). It also implies for some authors softness and weakness (van Dierendonck, 2011). Servant leadership theory is moreover criticized as too idealistic (Reinke, 2004) because the servant leader does not focus enough on results, but on the service itself (Gregory Stone et al., 2004). Another criticism by the same authors is the risk of manipulation (Gregory Stone et al., 2004). When the leader serves the follower, the follower might be psychologically obliged to return a favor. But are these criticisms valid?

A central value of servant leadership is its strong human orientation, its focus on serving. van Dierendonck and Nuijten (2011) note that in the discussions of servant leadership its 'people-centeredness', such as helping, serving and being authentic is often stressed. But, this does not mean that being a servant leader implies weakness or the failure to give direction and produce results. Kessler (2012) stresses this point by saying that it is a misunderstanding of servant leadership when insecure leaders seek to serve others but fail to provide leadership. Genuine leadership requires that direction is provided and goals are reached. Hence, a balance between serving on one hand and leading on the other hand needs to be maintained.

The human-centred approach of servant leadership counteracts the top-down tendencies of the new 'managerialism' and opens up a space for nurturing growth and creativity in 
academic groups. This is borne out in the work of scholars who have researched the links between leadership and creativity. Drawing on research into the effective leadership of scientists and engineers, Hemlin et al. (2013) argue that innovators expect and require academic leadership that is "based on expertise", including technical expertise, and that academic leaders are able to employ this expertise to produce practical outcomes, maintain a network of contracts and sell their products. Particularly important for this discussion is that such leaders are able to "create a work environment likely to facilitate creative work, an environment characterized by openness, safety, trust, and autonomy" and are able to "approach projects in an open, adaptive fashion, adjusting work to the local demands imposed by project development cycles and organizational expectations" (Hemlin et al., 2013). These attitudes and actions are particularly visible in servant leadership, hence its practice can facilitate creative and innovatory work within a group in any research field.

Another advantage of servant leadership is that it allows for a low power distance (van Dierendonck, 2011). In our view, this characteristic makes it a very valuable leadership approach for academic group leaders at contemporary higher education institutions in Germany, where academic freedom and autonomy have traditionally been highly prized.

It is noteworthy that Parris and Peachey (2013) have examined empirical studies on servant leadership and found that such studies began to appear after the year 2004. These studies were conducted in different contexts in Europe, North America, Africa, Asia and Australia. Only recently has an empirical study in the German context been conducted by Verdorfer and Peus (2014). These authors have used a German version of the multidimensional Servant Leadership Survey developed by van Dierendonck and Nuijten (2011). Their study is based on 533 participants from various branches of business.

It can be seen from this research that servant leadership models have been applied in different organizations, especially in the business and education sector. Studies of the latter include secondary and religious schools. Hence, it is likely that the servant leadership model is also well suited in the higher education context, although it appears that empirical studies on servant leadership have not yet been done within the higher education sector in Germany.

\section{Examples of ineffective and effective academic group leadership}

In a discussion on leadership in HEIs it is important to identify which leadership attributes and actions are ineffective, even damaging, and which are effective and beneficial. For example, aloof and obstructive behaviour on the part of academic group leaders in the supervision process diminishes their authority and provokes doctoral students to look for alternative promoters, or even lose their motivation to pursue $\mathrm{PhD}$ projects (Schmidt and Richter, 2008). Further, ineffective or unsatisfactory practice "... incorporated behaviour that was perceived as manifesting self-centredness, a self-aggrandisement-directed focus, selfabsorption and incompetence or inadequacy" (Evans et al., 2013). Conversely, supportive and meticulous supervision attracts students and enables them to complete their studies.

According to Haller (2007) the primary leadership deficiencies are (1) a lack of information and (2) a lack of appreciation. Bryman (2007) lists the following damaging leadership styles:

- Failing to consult 
- Not respecting existing values

- Actions that undermine collegiality

- Not promoting the interests of those for whom the leader is responsible

- Being uninvolved in the life of the department/institution

- Undermining autonomy

- Allowing the department/institution to drift

As noted by Laub and van Dierendonck above, servant leadership values, develops and empowers individual people, and encourages interpersonal acceptance and creativity. By displaying authenticity and being humble (as opposed to being untrustworthy and arrogant) academic group leaders can provide direction, build community and share leadership, thereby equipping others within the group to provide leadership at a later stage.

As an appointment or the receipt of a large research grant does not automatically enable a professor to be a good leader (Wheeler, 2012), academics who wish to exercise a leadership role can develop the necessary competencies (Strathe and Wilson, 2006). Thereby improved leadership relationships and skills can avoid ineffective and damaging behaviour on the part of academic group leaders. This does not mean that additional activities have to be added to the already very busy workday of a professor, rather improved leadership can enhance the tasks and activities that are already part of academic life (Schmidt and Richter, 2009) and avoid (or quickly resolve) those relational conflicts that easily impede the smooth functioning of an academic department.

Table 1 provides a list of the attributes that are associated with effective professorial leadership. These general attributes are relevant to higher education and other contexts (Haller, 2007), and comparable lists for effective leadership on a department level can be found in Bryman (2007) and Bland et al. (2002).

Table 1: Typical attributes of effective professorial leadership

$\begin{array}{ll}\text { Excellence through } & \text { - } \text { providing meaning and vision } \\ \text { professional leadership } & \text { - } \text { setting clear goals } \\ \text { (Peus et al., 2010a) } & \text { - } \text { providing freedom of action } \\ & \text { - } \text { appreciating the person and their performance } \\ & \text { - creating trust and fairness }\end{array}$

Typical role descriptions of a supervisor (Schmidt and Richter, 2008), own translation
- mentor / promoter

- partner / colleague

- organizer

- supporter

- role model

Characteristics of good

- goal orientation and effective leadership 


\begin{tabular}{|c|c|}
\hline $\begin{array}{l}\text { (Haller, 2007), } \\
\text { translation }\end{array}$ & $\begin{array}{l}\text { - } \text { be successful / achieve goals } \\
\text { - inform employees about plans and developments } \\
\text { - } \text { involve employees in strategic decisions } \\
\text { - } \text { transparency of decisions / clarification of values and } \\
\text { - } \text { rules } \\
\text { - } \text { apen communication } \\
\text { - } \text { show authenticity (walk the talk) } \\
\text { - } \text { equal treatment of employees, fair labor distribution } \\
\text { - demand performance from all colleagues } \\
\text { - } \text { authentic feedback / appreciation and criticism } \\
\text { - } \text { promote and develop employees } \\
\text { - give freedom } \\
\text { - } \text { appreciate the success of employees } \\
\text { - conflict tolerance (notice conflicts, tackle and seek to } \\
\text { - } \text { delve them) } \\
\text { - } \text { backing one's employees } \\
\text { - } \text { responsiveness } \\
\text { - } \text { be open to the personal interests of the employees }\end{array}$ \\
\hline $\begin{array}{l}\text { Key elements of } \\
\text { Fachhochschul professors' } \\
\text { professionalism (Vogel, } \\
2009 \text { ) }\end{array}$ & $\begin{array}{l}\text { - } \text { expert knowledge } \\
\text { - } \text { responsibility towards students } \\
\text { - } \text { autonomy } \\
\text { - } \text { effort } \\
\text { - } \text { research }\end{array}$ \\
\hline
\end{tabular}

The development of these characteristics and professional behavior, which are clearly in line with the type of servant leadership endorsed in this discussion, will certainly enhance academic group leadership, workplace relationships and the effectiveness of the relevant staff members and students.

\section{Servant leadership as a means of addressing the concrete needs and challenges of academic group leaders}

According to Fraune (2012), a university has different stakeholders that interact with each other in various ways with a multitude of different aims. The primary stakeholders are the 
university leadership, the professors, the research associates, student assistants, non-scientific research staff and, naturally, the students. Other stakeholders are the State which provides the main funding resources, external funding agencies such as the German Research Foundation (DFG) or the Federal Ministry of Education and Research (BMBF), and the local government.

In his review of servant leadership, van Dierendonck (2011) concludes that the operationalization of servant leadership is often missing; its practical implementation is often absent or insufficiently understood. We have also seen that servant leadership is sometimes criticized as being too unrealistic and impractical. But is this the case? Below, concrete suggestions are offered on how to operationalize servant leadership for the stakeholders of German higher education institutions and for the daily functioning of academic group leaders. Three areas of operationalization are noted below: developing academic leaders; serving the university and its stakeholders; and serving specific academic units.

Developing as servant academic group leader. Academic group leaders are important role models (Schmidt, 2010) both in terms of scientific rigor and aspects such as lifestyle, relationships, worldviews and ethics. Kouzes and Posner (2004) are right when they state how you 'spend your time is an important indicator of what's important for you' and stress the importance of modelling the way they wish others to adopt.

Becoming an effective academic group leader also concerns clarifying one's identity. With regard to servant leadership, Sun (2013) argues that the cognition and behaviour of a servant leader depends on his/her identity and he distinguishes between two approaches. In the servant-integrative approach the leader displays a high degree of unity in which s/he sees the need to display servant attributes across multiple situations and the servant-compartmentalized approach in which leaders can activate different identities in different situations (Sun, 2013). While he argues in favor of the latter, as it enables flexibility and takes the complexity of leadership in different situations into account, he regards both approaches as important.

While space does not permit a detailed discussion of leadership formation, it is reasonable to expect that academic group leaders who seek to operate as servant leaders will need to engage in a process of formation. Such formation will need to include the development of a person's moral character, professional knowledge, skills and relational abilities. Moral attributes such as fairness, responsibility, accountability, self-control and wisdom are vital aspects of credible leadership. Academic leaders with little professional knowledge, ability or reputation who may be foisted upon departments will simply not be respected, thus obstructing the whole-hearted co-operation of colleagues and staff. Furthermore, leaders with the skills to manage effectively the work of colleagues in a department and provide academic direction are much in demand. If they are also able to relate well to colleagues and staff, build community and resolve conflicts, their contribution will be invaluable. Conversely, untrustworthy, inept, lazy and self-aggrandizing individuals will not be effective academic group leaders. Academic leaders who take the trouble and effort to develop their capacities in these areas are likely to promote the teaching and research efforts of the university and/or department, and also contribute to the work of the university in the public sector. Informal reading, attending short courses/workshops on leadership offered within the university, engaging in formal studies, or implementing practices used by admirable colleagues are all means that could be employed to achieve the relevant ends.

Serving the university and its stakeholders. As the State is the main source of funds for most universities the primary, and obvious, service to be rendered by academic group 
leaders is to ensure excellence in the provision of the teaching, research and administration of the university's degrees and courses. By pursing both academic excellence and service to the wider society, members of the university win credibility and contribute to the lives of others.

It has already been noted that academic group leaders ought to be seen as being part of a university's general management. Thus, in order to serve the university, the academic group leader should endeavour to earn a good reputation within the research community based on his/her academic expertise (Fraune, 2012). The academic group leader can also contribute to committee work and academic self-government at department and university level. By being an excellent researcher and teacher, and an effective leader who has positive public relations, an academic group leader serves the higher education sector as a whole. Examples of other tasks that promote higher education are the willingness to act as an external examiner and a peer reviewer of academic publications.

External funding agencies can be served by the submission of high quality research proposals and, wherever possible, the delivery of the promised outcomes. Academic group leaders can further serve external funding agencies by being reliable partners and diligently reviewing grant applications and reports.

In addition, academics within the university can serve the State and local government by providing academic service learning courses, through which the students can learn social responsibility. Such practical engagement includes working with refugees, starting poverty alleviation projects and passing on valuable skills (Moll et al., 2016). Academic service learning is a well-established and researched approach that facilitates learning through practical engagement (Butin, 2005). It also awakens students to the needs of others, thereby contributing to the empowerment and moral formation of future leaders and the development of their knowledge and skills. The importance of this 'third mission' is becoming more and more important for universities in Germany.

Serving specific academic units. Academic group leaders are called upon to serve members of their teaching and research teams (including academic colleagues, research associates, student assistants and non-academic staff) and, in particular their students. This can be done by ensuring the excellence of their work and facilitating their professional and/or educational development. Drawing on the ten characteristics of servant leadership as listed by Spears (2004) earlier in this discussion, we point out some concrete ideas on how to implement servant leadership in the daily practice of an academic group leader, both for the group as a whole and for individual group members.

The promotion of good relationships is important for servant leaders (van Dierendonck, 2011). In practice, rather than being an 'absentee academic' this means being present at the University, diligently reading the work of students and spending time talking to them about their studies (listening, empathy). The academic group leader can optimize the environmental variables (foresight, stewardship), i.e. the working conditions, to increase research productivity by facilitating a distinctive research culture, a positive group climate, assertive participative governance, etc. (Bland and Ruffin cited Ramsden, 1998).

Since a fruitful dialogue is regarded by students as good supervision (Agu and Odimegwu, 2014) supervisors should invest time in the relationship with their doctoral students. In addition, the academic group leader can encourage and help the students to prepare publications in order to establish their own standing in the research community (commitment 
to growth). $\mathrm{PhD}$ students can be encouraged to give presentations at conferences and take training courses offered by the university that are related to 'soft' skills, such as the use of the voice, body language and presentation techniques. With reference to the mentoring of junior colleagues, it is interesting that a study in the United Kingdom revealed that “...63.7 per cent of respondents 'definitely agree' that it should be a requirement of the professorial role to 'have a responsibility to advise non-professorial colleagues and help them develop professionally', and 30.0 per cent 'agree to some extent"' (Evans et al., 2013).

As already noted, academic leaders are sometimes criticised for a lack of communication and an inadequate flow of information within their department or section. Hence academic group leaders should aim at a fair and effective flow of information, for example by means of regular meetings. This is important because information is a significant source of power in an organization (Kessler, 2012).

Holding regular weekly meetings of the whole working group supports the exchange and relationships between the group members (awareness, building community). Short presentations can be used to inform each group member about the current research activities of other group members. This forum can also be used to communicate important information related to running projects, or the introduction of new members to the working group (including post graduate students). These meetings also provide an opportunity to discuss short-term and long-term goals for the whole group (foresight, conceptualizing). The group leader can use these meetings to inspire the group and present the big picture. Moreover, difficult or unpleasant topics can be explained in a transparent way (persuasion) to avoid the development of suspicion and to promote the sharing of information and transparency. Such meetings are central for building trust and creating a common sense approach within the working group. The group meetings are particularly important for foreign $\mathrm{PhD}$ students, enabling them to become more involved in the group and to have the opportunity to improve their language skills.

Some meetings can be informal and open-ended, taking place during a meal or when the group meets to celebrate particular achievements (e.g. an important publication or obtaining a research grant) or share personal milestones (e.g. birthdays). It is important to create opportunities for members of academic groups to sit together and talk or to attend social events together (e.g. sporting or cultural events). This can improve the atmosphere within the group and strengthen the identification of members with the academic group (building community).

The academic group leader can further have regular formal and informal meetings with individual members of the working group (listening). In these meetings, the servant leader can discuss issues such as their work, the progress of their dissertation, their professional situation and even their personal wellbeing. In the case of personal problems, it may be possible to find solutions in order to alleviate or overcome difficult situations (healing). These short-term and long-term goals of academic colleagues and postgraduate students can also be discussed formally (e.g. annual appraisals) or in informal discussions over a cup of coffee (foresight, persuasion), and feedback provided about their professional development (stewardship, commitment to growth).

On a more personal level and when appropriate, it can be helpful for academic leaders to share some aspect of their own experience to reduce the power distance (empathy) and offer the opportunity for a group member to share his/her problems and suggest means that can help individuals to overcome these problems (awareness). This can result in concrete actions, e.g. when an optimization of the working environment is required or if someone - due to personal 
circumstances - needs a few days off. In the case of a conflict between group members, the group leader can help to solve the conflict (healing). The 'open door' of a leader's office shows his/her willingness to engage in discussion (listening, empathy, building community).

\section{Conclusion}

This article has argued that servant leadership is a suitable leadership model for academic group leaders in the context of German universities, especially because servant leadership has a strong human orientation and a low power distance (van Dierendonck, 2011). Both aspects are important in the context of higher education because creativity and innovation in the areas of teaching and research occur most often when both partners can communicate openly and because the supervisor-student relationship is so important for the success of a $\mathrm{PhD}$ project. At the end of a large-scale study in Germany, it was found by Fraune (2012) that top-down or hierarchical control mechanisms are not effective for the German university setting. Hence, the more facilitative, bottom-up approach of servant leadership, with its strong focus on promoting academic excellence, providing direction for the department and being aware of the needs of colleagues and students appears to be more advantageous. To achieve the successful implementation of servant leadership, it is essential to balance the caring dimensions and the dimensions of providing vision, direction, fair treatment, academic excellence and opportunities for professional development.

In the context of the current focus on new managerialism, academic group leaders need to resist its overly controlling and bureaucratic elements and function in an efficient manner within their own spheres of influence. The approach of servant leadership can result in better teaching and research, the improved exercise of leadership responsibilities, academic collegiality, shared leadership, the retention of academic freedom and a better balance of academic and managerial power within the university. In essence, servant leadership on the part of an academic group leader means combining moral integrity, good research, social responsibility and accountability and being both available to one's colleagues, students and other important stakeholders. 


\section{References}

Acker S (2012) Chairing and caring: gendered dimensions of leadership in academe. Gender and Education 24(4): 411-428.

Agu N and Odimegwu CO (2014) Doctoral Dissertation Supervision: Identification and Evaluation of Models. Education Research International 2014(3): 1-9.

Barbuto JE (2006) Scale Development and Construct Clarification of Servant Leadership. Group \& Organization Management 31(3): 300-326.

Bekker CJ (2010) Prophet and Servant: Locating Robert K. Greenleaf's Counter-Spirituality of Servant Leadership. The Journal of Virtues \& Leadership 1(1): 3-14.

Berger T (2014) Servant Leadership 2.0: A Call for Strong Theory. Sociological Viewpoints 30(1): 146-167.

Bland CJ, Seaquist E, Pacala JT, Center B and Finstad D (2002) One school's strategy to assess and improve the vitality of its faculty. Academic Medicine 77(5): 368-376.

Braun S, Nazlic T, Weisweiler S, Pawlowska B, Peus C and Frey D (2009) Effective leadership development in higher education: Individual and group level approaches. Journal of Leadership Education 8(1): 195-206.

Bryman A (2007) Effective Leadership in Higher Education: Summary of Findings: Leadership Foundation of Higher Education.

Butin DW (2005) Service-learning in higher education: Critical issues and directions. New York: Palgrave Macmillan.

Carmesin B, Hoffmann U, Huskobla G, Huster S, Küster J, Neumann J, et al. (2014) Betreuung Promovierender. Empfehlungen und Good Practice für Universitäten und Betreuende: UniWiND-Publikationen.

Eicher-Catt D (2005) The myth of servant-leadership: A feminist perspective. Women and Language 28(1): 17-25.

Evans L, Homer M and Rayner S (2013) Professors as Academic Leaders: The Perspectives of 'the Led'. Educational Management Administration \& Leadership 41(5): 674-689.

Federal Statistical Office (2016a) Statistics on higher education in Germany - Part 1. Available at: https://www.destatis.de/DE/ZahlenFakten/GesellschaftStaat/BildungForschungKultur/Ho chschulen/Tabellen/HochschulenHochschularten.html [last accessed: 15 July 2016].

Federal Statistical Office (2016b) Statistics on higher education in Germany - Part 2. Available at: https://www.destatis.de/DE/ZahlenFakten/GesellschaftStaat/BildungForschungKultur/Ho chschulen/Hochschulen.html\#Tabellen [last accessed: 15 July 2016]. 
Flanike F (2006) Is the Bible relevant to servant-leadership? Journal of Applied Christian Leadership 1(1): 32-39.

Fraune C (2012) Stakeholder von Universitäten: Eine gegenwarts- und zukunftsorientierte Anforderungsanalyse. Siegen - Saarbrücken, KORFU-Arbeitspapier Nr. 4.

Greenleaf RK (1977) Servant leadership: New York: Paulist Press.

Gregory Stone A, Russell RF and Patterson K (2004) Transformational versus servant leadership: a difference in leader focus. Leadership \& Organization Development Journal 25(4): 349-361.

Haller R (2007) Mitarbeiterführung in Wissenschaft und Forschung: Grundlagen, Instrumente, Fallbeispiele ; [mit Hinweisen zur Umsetzung der leistungsorientierten Vergütung nach TVöD]. Berlin: BWV, Berliner Wiss.-Verl.

Hans Böckler Stiftung (2010) Das Leitbild Demokratische und Soziale Hochschule: Vorschlag für die Hochschule der Zukunft.

Hemlin S, Allwood C, Martin B and Mumford M (2013) Why Is Leadership Important for Creativity in Science, Technology, and Innovation? In: Martin BR, Allwood CM, Mumford MD and Hemlin S (eds) Creativity and leadership in science, technology, and innovation. New York: Routledge, pp. 1-23.

Hüther O (2010) Von der Kollegialität zur Hierarchie?: Eine Analyse des New Managerialism in den Landeshochschulgesetzen. Wiesbaden: Springer Fachmedien.

Jeynes W and Robinson DW (2012) International Handbook of Protestant Education. s.1.: Springer Netherlands.

Jungbauer-Gans M and Gross C (2013) Determinants of success in university careers: findings from the German academic labor market. Zeitschrift für Soziologie 42(1): 74-92.

Kessler V (2012) Vier Führungsprinzipien der Bibel. Gießen: Brunnen-Verlag.

Kessler V and Kretzschmar L (2015) Christian Leadership as a trans-disciplinary field of study. Verbum et Ecclesia 36(1): 1-8.

Klinkhammer M (2014) Coaching für Wissenschaftler/innen. In: Wegener R, Loebbert M and Fritze A (eds) Coaching-Praxisfelder. Forschung und Praxis im Dialog. Wiesbaden: Springer Fachmedien Wiesbaden, pp. 73-93.

Kouzes JM and Posner BZ (2004) Christian reflections on The leadership challenge. San Francisco, CA: Jossey-Bass.

Krimmer H, Stallmann F, Behr M and Zimmer A (2004) Karrierewege von Professorinnen an Hochschulen in Deutschland. 
Laub JA (1999) Assessing the servant organization: Development of the servant organizational leadership assessment (SOLA) instrument: Florida Atlantic University, Dissertation.

Macfarlane B (2007) The academic citizen: The virtue of service in university life. London, New York: Routledge.

Macfarlane B (2012) Intellectual leadership in higher education: Renewing the role of the university professor. New York: Routledge.

McClellan JL (2013) Contributing to the Development of Student Leadership through Academic Advising. Journal of Leadership Education 12(1): 207-233.

Middlehurst R, Goreham H and Woodfield S (2009) Why Research Leadership in Higher Education? Exploring Contributions from the UK's Leadership Foundation for Higher Education. Leadership 5(3): 311-329.

Moll J, Kreikebaum M, Cole P, Kiiza M and Holtkamp S (2016) Social Responsibility of Higher Education Institutions: Service Learning Cooperation between Germany and Uganda. In: Barentsen J, Kessler V and Meier E (eds) Christian Leadership in a Changing World: Perspectives from Africa and Europe. Leuven: Peeters Publ., pp. 201215.

Parris DL and Peachey JW (2013) A Systematic Literature Review of Servant Leadership Theory in Organizational Contexts. Journal of Business Ethics 113(3): 377-393.

Peus C, Braun S, Weisweiler S and Frey D (2010a) Kompetent führen, führend forschen?: Professionalisierung der Führungskompetenz an deutschen Universitäten.

OrganisationsEntwicklung 29: 38-45.

Peus C, Kerschreiter R, Frey D and Traut-Mattausch E (2010b) What is the value?: Economic Effects of Ethically-Oriented Leadership. Journal of Psychology 218(4): 198212.

Ramsden P (1998) Learning to lead in higher education. London, New York: Routledge.

Rayner S, Fuller M, McEwen L and Roberts H (2010) Managing leadership in the UK university: a case for researching the missing professoriate? Studies in Higher Education 35(6): 617-631.

Reinke S (2004) Service before self: Towards a theory of servant leadership. Global Virtue Ethics Review 5(3): 30-57.

Rowley DJ and Sherman H (2003) The special challenges of academic leadership. Management Decision 41(10): 1058-1063.

Schmidt B (2010) Mit gutem Beispiel voran?: Eine empirische Studie zum veränderungsund innovationsbezogenen Handeln von Professorinnen und Professoren. die hochschule(1): 46-63. 
Schmidt B and Richter A (2008) Unterstützender Mentor oder abwesender Aufgabenverteiler? - Eine qualitative Interviewstudie zum Führungshandeln von Professorinnen und Professoren aus der Sicht von Promovierenden. Beiträge zur Hochschulforschung 4(30): 34-58.

Schmidt B and Richter A (2009) Zwischen Laissez-Faire, Autokratie und Kooperation: Führungsstile von Professorinnen und Professoren. Beiträge zur Hochschulforschung 31(4): 8-35.

Sendjaya S and Sarros JC (2002) Servant Leadership: Its Origin, Development, and Application in Organizations. Journal of Leadership \& Organizational Studies 9(2): 5764.

Spears LC (2004) Practicing servant-leadership. Leader to Leader 2004(34): 7-11.

Strathe MI and Wilson VW (2006) Academic leadership: The pathway to and from. New Directions for Higher Education 2006(134): 5-13.

Sun PY (2013) The servant identity: Influences on the cognition and behavior of servant leaders. The Leadership Quarterly 24(4): 544-557.

van Dierendonck D (2011) Servant Leadership: A Review and Synthesis. Journal of Management 37(4): 1228-1261.

van Dierendonck D and Nuijten I (2011) The Servant Leadership Survey: Development and Validation of a Multidimensional Measure. Journal of business and psychology 26(3): 249-267.

Verdorfer AP and Peus C (2014) The Measurement of Servant Leadership. Zeitschrift für Arbeits- und Organisationspsychologie A\&O 58(1): 1-16.

Vogel MP (2009) The professionalism of professors at German Fachhochschulen. Studies in Higher Education 34(8): 873-888.

Weisweiler S, Peter T, Peus C and Frey D (2011) Personalentwicklung für Wissenschaftler/innen Personalentwicklung für Wissenschaftler/innen Professionalisierung von Selbst-, Führungs- und Lehrkompetenzen. Zeitschrift für Hochschulentwicklung 6(3): 325-340.

Wheeler DW (2012) Servant leadership for higher education: Principles and practices. San Francisco, Calif.: Jossey-Bass.

\section{Author Biographies}

Jochen Moll (Dr.-Ing.) is a postdoctoral researcher in the Department of Physics at the Goethe-University of Frankfurt am Main, Germany. He is the Coordinator of a collaborative research project and principal investigator of a European ERA-Net project. He had several leadership positions and published more than 70 scientific publications. (Corresponding Author) 
Louise Kretzschmar (Ph.D) is a Professor of Theological Ethics at the University of South Africa where she has tuition, research and community engagement responsibilities. Along with a focus on Christian ethics, she has a strong practical and research interest in Christian Spirituality, Leadership and Applied Ethics. 